Abstracta Iranica Abstracta Iranica

Revue bibliographique pour le domaine irano-aryen

Volume 28 | 2007

Comptes rendus des publications de 2005

\title{
The Persian Empire, A History. The British Museum Press, London, 208 p., bibliographie, index., 160 plans NB et fig. coul.
}

\section{Rémy Boucharlat}

\section{(2) OpenEdition}

Journals

Édition électronique

URL : http://journals.openedition.org/abstractairanica/15142

DOI : 10.4000/abstractairanica.15142

ISSN : 1961-960X

Éditeur :

CNRS (UMR 7528 Mondes iraniens et indiens), Éditions de l'IFRI

\section{Édition imprimée}

Date de publication : 15 mai 2007

ISSN : 0240-8910

Référence électronique

Rémy Boucharlat, "The Persian Empire, A History. The British Museum Press, London, 208 p. bibliographie, index., 160 plans NB et fig. coul. », Abstracta Iranica [En ligne], Volume 28 | 2007, document 62, mis en ligne le 18 septembre 2007, consulté le 25 septembre 2020. URL : http:// journals.openedition.org/abstractairanica/15142; DOI : https://doi.org/10.4000/abstractairanica. 15142

Ce document a été généré automatiquement le 25 septembre 2020.

Tous droits réservés 


\title{
The Persian Empire, A History. The British Museum Press, London, 208 p., bibliographie, index., 160 plans NB et fig. coul.
}

\author{
Rémy Boucharlat
}

1 Ce "guide", comme le qualifie modestement son auteur, concerne l'histoire, le fonctionnement et les réalisations de l'empire achéménide. En six pages d'introduction très accessibles au non spécialiste, l'A. tente d'expliciter quelques termes souvent mal compris, de décrire les sources disponibles et les immenses lacunes, et annonce la prudence dont elle fera preuve tout au long du livre. On retrouve le souci d'une lecture aisée ou à un niveau rapide dans les légendes des illustrations, développées et claires. Le texte lui-même est bien informé, expose les hypothèses les plus récentes et les opinions divergentes ou trop simplistes: par ex., dans le chap. 3 sur les résidences royales, la description, plus symbolique que réelle, des peuples qui fournirent les matériaux du palais de Darius à Suse, ou ceux qui les travaillèrent, la fonction des différents bâtiments de Persépolis, dont le nom fut en général donné par les fouilleurs, l'absence de constructions ou de lieux religieux identifiables, la célébration du Nouvel An qui aurait vu la venue simultanée des délégations de tout l'empire. Des notes très fournies et précises satisferont le lecteur plus spécialiste.

2 L'histoire politique de l'empire après Xerxès et ses relations avec le monde grec (chap. 4), les religions et le rôle du roi dans le mazdéisme (chap. 5) sont également traités de manière très équilibrée. Le chap. 6 traite de la conquête d'Alexandre et de l'image de celui-ci dans la littérature et les arts d'Orient et d'Occident. Le chap. 7 réunit les témoignages archéologiques et épigraphiques laissés par les dynasties postérieures (sassanide et bouyide principalement) à Persépolis et dans sa région, puis un résumé de la redécouverte de Persépolis par les voyageurs et marchands européens aux XVI ${ }^{\mathrm{e}}$ XVIII ${ }^{e}$ siècles, chez qui la fonction religieuse du site et le lieu de célébration du Nouvel An sont des questions redondantes. Enfin, les premiers «prélèvements » de sculptures 
à Persépolis et les premières fouilles, les réactions iraniennes, mais aussi l'engouement local pour le style et l'iconographie de l'art achéménide qui sont imités dans les riches demeures de Shiraz et d'autres villes, avant que certains motifs deviennent des emblèmes en Iran du début du XX $\mathrm{X}^{\mathrm{e}} \mathrm{s}$. jusqu'à aujourd'hui.

3 Un livre très équilibré dans la présentation des données et l'état des questions, de lecture facile, mais riche en données (la bibliographie utilisée va jusqu'à 2003 mais inclut des références jusqu'à 2005 et à venir) qui sont très utiles pour le spécialiste.

INDEX

Thèmes : 3.2.2. Pré-Achéménides et Achéménides

\section{AUTEURS}

RÉMY BOUCHARLAT

IFRI/CNRS - Téhéran/Lyon 